\title{
Biomarkers for acute kidney injury
}

\author{
Dildar Konukoglu
}

Department of Medical Biochemistry, Istanbul University, Cerrahpasa Faculty of Medicine, Istanbul, Turkey

\begin{abstract}
Objectives: Acute kidney injury (AKI) is associated with both a number of adverse outcomes and with morbidity and mortality. Therefore, early diagnosis of AKI is very important. Several novel AKI biomarkers have been found and studied. Markers include impaired filtration barriers, reduced tubular reabsorption, increased release of tubular proteins due to cell damage and/or activation of inflammatory cells, and the release of activation products in response to injury. Neutrophil gelatinase-associated lipocalin, kidney injury molecule 1, interleukin-18, liver-type fatty acid-binding protein, cystatin C, tissue inhibitor of metalloproteinase-2, and insulin-like growth factor-binding protein 7 markers appear to be useful; however, the clinical uses of AKI biomarkers are not yet well defined and the number of clinical trials is limited. Additionally, analytical validation of tests for AKI markers is also required. Therefore, measurement of the daily quantity of urine and determination of blood urea and creatinine levels are most often used for both diagnosis and classification of AKI in clinical practice.

Keywords: Acute kidney injury, cystatin c, insulin-like growth factor-binding protein 7, interleukin-18, kidney injury molecule 1, liver-type fatty acid-binding protein, neutrophil gelatinase-associated lipocalin, tissue inhibitor of metalloproteinase-2
\end{abstract}

A cute kidney injury (AKI) is the sudden loss of kidney function. It has been referred to as acute kidney failure in the past. The primary physiological function of the kidneys is to filter the blood and remove the waste, as well as excess salt and water. When AKI occurs, urea nitrogen and creatinine levels increase in the blood circulation, the daily urine output falls, and the fluid-electrolyte balance and the acid-base balance deteriorate. AKI is associated with prerenal, renal, and postrenal events (Table 1). Although AKI is often reversible, depending on the causes and severity, it may not be. The most common adverse events due to $\mathrm{AKI}$ are chronic renal failure, chronic kidney disease, and cardiovascular events. AKI is a major cause of morbidity and mortality in intensive care units. Therefore, early diagnosis of $\mathrm{AKI}$ is very important for the prognosis of patients as well as to reduce medical costs [1-6].

To diagnose $\mathrm{AKI}$, the measurement of the daily quantity of urine output; routine urinalysis; blood tests examining urea and creatinine levels; imaging tests, such as ultrasound and computerized tomography; and/or a kidney biopsy may be performed. Regulation of blood pressure and circulation of the blood to the kidneys are primary treatments for patients with AKI. Shortterm dialysis is used in some cases, but long-term dialysis or kidney transplantation may be required for patients with severe renal insufficiency $[7,8]$.

Several classification schemes have been proposed for patients with $\mathrm{AKI}$ according to the extent and duration of renal injury and to predict clinical outcomes (Table 2). The classification systems contain criteria for serum creatinine $(\mathrm{SCr})$ and urine output. The KDIGO (Kidney Disease: Improving Global Outcomes) criteria for AKI diagnosis are: SCr level increase more than 0.3 $\mathrm{mg} / \mathrm{dL}$ in 48 hours, or SCr level increase 1.5-fold over baseline within 7 days, or urine volume of less than $0.5 \mathrm{~mL} / \mathrm{kg} / \mathrm{hour}$ for 6 hours (also referred as Stage 1). In addition to the 3 stages of renal dysfunction, the RIFLE (Risk of renal dysfunction, Injury to the kidney, Failure of kidney function, Loss of kidney function and End-stage kidney disease) criteria, unlike KDIGO includes 2 additional clinical outcomes of loss, indicating the complete loss of kidney function and end-stage renal disease, requiring renal replacement therapy [7-11].

Address for correspondence: Dildar Konukoglu, Department of Medical Biochemistry, Istanbul University, Cerrahpasa Faculty of Medicine, Istanbul, Turkey Phone: +90 2124143000 E-mail: dkonuk@yahoo.com ORCID: 000000026095 264X

Accepted Date: May 08, 2018 Available Online Date: June 04, 2018

${ }^{\circ}$ Copyright 2018 by International Journal of Medical Biochemistry - Available online at www.internationalbiochemistry.com 


\section{Table 1. The main causes of acute kidney injury}

\section{Factors \\ Prerenal factors - related to the decrease in blood volume \\ Renal factors - related to damage to the glomeruli or the tubes leading from the glomeruli}

Post renal factors - related to obstruction of the urine flow

\section{Causes}

-Heart failure

- Liver failure

-Shock

- Infection

- Cancer

-Some medications

-Nephrotoxins

-Autoimmune diseases

- Cancers related to urinary tract

-Prostate problems in men

\section{Table 2. KDIGO, AKIN, and RIFLE criteria for acute kidney injury}

\section{KDIGO criteria}

Definition of AKI: Increase in $\mathrm{SCr} \geq 0.3 \mathrm{mg} / \mathrm{dL}$ within $48 \mathrm{~h}$ or $\geq 50 \%$ within $7 \mathrm{~d}$

\section{Stage}

1

2

3

\section{Serum creatinine}

- $\mathrm{SCr} \geq 0.3 \mathrm{mg} / \mathrm{dL}$ within $48 \mathrm{~h}$ OR

-SCr to 1.50-1.99 times baseline over $7 \mathrm{~d}$

- $\mathrm{SCr}$ to 2.00-2.99 times baseline

- $\mathrm{SCr}$ to 3.00 times baseline -OR

- $\mathrm{SCr}$ increase to $\geq 4 \mathrm{mg} / \mathrm{dL}$

-Initiation of RRT

-Anuria for $\geq 12 \mathrm{~h}$

\section{Urine output}

$\bullet<0.5 \mathrm{~mL} / \mathrm{kg} / \mathrm{h}$ for $6-12 \mathrm{~h}$

$\bullet<0.5 \mathrm{~mL} / \mathrm{kg} / \mathrm{h}$ for more than $12 \mathrm{~h}$

$\bullet<0.3 \mathrm{~mL} / \mathrm{kg} / \mathrm{h}$ for more than $24 \mathrm{~h}$ OR

\section{AKIN criteria}

Definition of AKI: Increase in SCr $\geq 0.3 \mathrm{mg} / \mathrm{dL}$ or $\geq 50 \%$ within $48 \mathrm{~h}$

1

2

3

\section{RIFLE criteria}

\section{Definition of AKI: Increase in $\mathrm{SCr} \geq \mathbf{5 0 \%}$ within $\mathbf{7 d}$}

Risk

Injury

Failure

Loss

End stage
-SCr $\geq 0.3 \mathrm{mg} / \mathrm{dL} \mathrm{SCr}$ increase within $48 \mathrm{~h}$ OR

- $\mathrm{SCr}$ to $>1.5-2.0$ times baseline

- $\mathrm{SCr}$ to $>3-4$ times baseline

- $\mathrm{SCr}$ to $>3$ times baseline, OR

- $\mathrm{SCr}$ to $>4 \mathrm{mg} / \mathrm{dL}$ with an acute increase of $>0.5 \mathrm{mg} / \mathrm{d}$ OR -Initiation of RRT

-Anuria for $\geq 12 \mathrm{~h}$

$\cdot \mathrm{SCr} \geq 1.5 \mathrm{x}$ baseline increase within $7 \mathrm{~d}$, sustained for $\geq 24 \mathrm{~h}$

- $\mathrm{SCr}$ to $\geq 2 \mathrm{x}$ baseline increase

-Anuria for $\geq 12 \mathrm{~h}$

- $\mathrm{SCr}$ to $>3 \mathrm{x}$ baseline increase OR

- $\mathrm{SCr}$ increase to $\geq 4 \mathrm{mg} / \mathrm{dL}$ (with increase of $\geq 0.5 \mathrm{mg} / \mathrm{dL}$ )

-Complete loss of kidney function for $>4 \mathrm{wk}$

-Need for RRT for $>3$ mo $\cdot<0.5 \mathrm{~mL} / \mathrm{kg} / \mathrm{h}$ for $6-12 \mathrm{~h}$

$\bullet<0.5 \mathrm{~mL} / \mathrm{kg} / \mathrm{h}$ for more than $12 \mathrm{~h}$

$\cdot<0.3 \mathrm{~mL} / \mathrm{kg} / \mathrm{h}$ for more than $24 \mathrm{~h}$ OR

$\bullet<0.5 \mathrm{~mL} / \mathrm{kg} / \mathrm{h}$ for more than $12 \mathrm{~h}$

$\cdot<0.3 \mathrm{~mL} / \mathrm{kg} / \mathrm{h}$ for more than $24 \mathrm{~h}$ OR

$\cdot<0.5 \mathrm{~mL} / \mathrm{kg} / \mathrm{h}$ for more than $12 \mathrm{~h}$

AKI: Acute kidney injury; AKIN: Acute Kidney Injury Network; KDIGO: Kidney Disease: Improving Global Outcomes; RIFLE: Risk of renal dysfunction, Injury to the kidney, Failure of kidney function, Loss of kidney function and End-stage kidney disease; RRT: Renal replacement therapy; SCr, Serum creatinine.

The common point of these systems is the use of SCr level or the estimated glomerular filtration rate for classification. Although $\mathrm{SCr}$ is the gold-standard marker for renal function, $\mathrm{SCr}$ levels are related to age, sex, body muscle mass, dietary factors, and blood volume status. The use of glomerular filtration rate esti- mation was an attempt to overcome this issue [12-14]. SCr is not reliable in patients with sepsis, liver disease, muscle wasting, or fluid overload. Furthermore, it does not provide any information regarding the underlying etiology. Measurement of $\mathrm{SCr}$ concentration is an essential approach for the determination of 
glomerular function. The $\mathrm{SCr}$ level also becomes very important when the kidneys have less than $50 \%$ of the nephron count. AKI may also be present with a normal creatinine level, if it is sufficiently elevated above baseline [15-19]. The "injury" label, which is now used instead of "failure," reflects different circumstances. "Failure" is associated with the loss of glomerular filtration ability of the kidney, whereas "injury" refers to pathologies before a decrease in glomerular filtration. Therefore, biomarkers that can demonstrate the damage before the glomerular filtration rate is affected would be very useful $[20,21]$.

\section{Biomarkers for AKI}

Within the past 20 years, several novel potential biomarkers (Table 3) have been studied in the urine or blood of AKI pa-

\begin{tabular}{|c|c|}
\hline Indication of & Markers \\
\hline \multirow[t]{7}{*}{ Glomerular function } & -Cystatin C \\
\hline & -Neutrophil gelatinase-associated \\
\hline & lipocalin \\
\hline & -Retinol binding protein 4 \\
\hline & •Hepcidin \\
\hline & -Galectin-3 \\
\hline & ·Proenkephalin \\
\hline \multirow[t]{4}{*}{ Tubular function } & -Cystatin C \\
\hline & -Neutrophil gelatinase-associated \\
\hline & lipocalin \\
\hline & - Retinol binding protein 4 \\
\hline \multirow[t]{2}{*}{ Renal inflammation } & -Calprotectin \\
\hline & •Interleukin-18 \\
\hline Damage & -N-acetyl-D-glucosaminidase ${ }^{a}$ \\
\hline${ }^{a} a$ cell cycle arrest marker & $\cdot \gamma$-glutamyl transpeptidase ${ }^{a}$ \\
\hline \multirow[t]{18}{*}{${ }^{b} a$ nephrotoxicity marker } & -Glutathione S-transferase ${ }^{a}$ \\
\hline & -Alanine aminopeptidase ${ }^{a}$ \\
\hline & - Lactate dehydrogenase ${ }^{a}$ \\
\hline & $\begin{array}{l}\text {-Insulin-like growth factor-binding } \\
\text { protein } 7^{b}\end{array}$ \\
\hline & -Tissue inhibitor of \\
\hline & metalloproteinases- $2^{\mathrm{b}}$ \\
\hline & •Kidney injury molecule \\
\hline & -Liver-type fatty acid-binding \\
\hline & protein \\
\hline & -Neutrophil gelatinase-associated \\
\hline & lipocalin \\
\hline & •Retinol-binding protein \\
\hline & -Interleukin-18 \\
\hline & $\cdot a 1 / \beta 2$ microglobulin \\
\hline & -MicroRNA, miRNA-201, and \\
\hline & miRNA-21 \\
\hline & •Netrin-1 \\
\hline & -Clusterin \\
\hline
\end{tabular}

Table 4. Diagnostic and prognostic plasma and urine biomarkers for acute kidney injury

\begin{tabular}{ll}
$\begin{array}{l}\text { Diagnostic biomarkers } \\
\text { for AKI }\end{array}$ & Prognostic biomarkers for AKI \\
\hline Plasma or urinary NGAL & Plasma or urinary NGAL \\
Urinary KIM-1 & Urinary KIM-1 \\
Urinary L-FABP & Urinary L-FABP \\
Urinary IGFBP7 & Urinary interleukin -18 \\
Urinary TIMP-2 & Urinary angiotensinogen \\
N-acetyl- $\beta$ D- & Urinary miRNA-210 and miRNA-21 \\
glucosaminidase & \\
Urinary interleukin-18 & \\
Urinary calprotectin & \\
Urinary angiotensinogen & \\
Urinary miRNA-210 and & \\
miRNA-21 & \\
$\beta 2$ microglobulin & \\
a1-microglobulin &
\end{tabular}

AKI: Acute kidney injury; IGFBP7: Insulin-like growth factor-binding protein 7; KIM-1: Kidney injury molecule 1; L-FABP: Liver-type fatty acid-binding protein; NGAL: Neutrophil gelatinase-associated lipocalin; TIMP-2: Tissue inhibitor of metalloproteinase 2 .

tients. The anatomical origins, physiological functions, kinetics, and release time of these markers in response to renal damage differ significantly [22-27]. The mechanisms associated with renal damage markers are:

1. Impaired filtration barriers

2. Reduced tubular reabsorption

3. Increased release of tubular proteins due to cell damage

4. Activation of inflammatory cells and release of activation products in response to injury

Urinary biomarkers are non-invasive, and easily measurable and obtainable in comparison with blood biomarkers. Different biomarkers are excreted in the urine according to the localization of the injury.

The secretion site of markers indicating acute renal injury are summarized below [22-23]:

Proximal tubules: Kidney injury molecule-1 (KIM-1), clusterin, neutrophil gelatinase-associated lipocalin (NGAL), tissue inhibitor metalloproteinase 2 (TIMP-2), a-glutathione-S-transferase (a-GST), $\beta$-2-microglobulin, $a-1$ microglobulin, $\mathrm{N}$-acetyl$\beta$-D-glucosaminidase (NAG), osteopontin, urinary cystatin $C$, netrin-1, retinol binding protein (RBP), interleukin-18 (IL-18), hepatocyte growth factor (HGF), exosomal fetuin-A, liver-type fatty acid-binding protein (L-FABP), micro RNAs, insulin growth factor- binding protein 7 (IGFBP7), albumin

Glomerulus: Total protein, creatinine, cystatin C, $\beta$-2-microglobulin, podocalyxin, albumin

Distal tubules: Osteopontin, clusterin, NGAL, GST, L-FABP, calbindin D28 


\section{Collecting duct: Calbindin D28}

Henle loop: Osteopontin

While excretion of high-molecular weight protein can be associated with glomerular injury, low-molecular weight proteinuria is associated with kidney tubulus damage. Some biomarkers reflect structural injury (KIM-1, NAG, NGAL, interleukin-8, TIMP-2, clusterin), some biomarkers are related to functional injury (cystatin $C$; total protein; albumin; $\beta-2$ microglobulin; urinary enzymes, such as NAG, cathepsin $B$, and $\beta$-glucosidase; brush border and tubular antigens; fetuin-A; type IV collagen; L-FABP; retinol binding protein 4; Tamm-Horsfall glycoprotein). NGAL and cystatin $C$ are available in both serum and urine. While some biomarkers reflect reversible, functional change of the kidneys, the biomarkers associated with functional injury have been accepted as late biomarkers of kidney dysfunction [22-28].

\section{What are the characteristics of the ideal marker for AKI?}

The ideal biomarker for AKI would be an increase in a few minutes or hours after the onset of kidney failure and would remain elevated for as long as the kidney damage persists. The level would be quantitatively correlated with the level of kidney damage and decrease in proportion to kidney recovery [26]. Biomarkers for AKI have provided some benefits to the management of patients with $A K I$, and some are used routinely in the clinic [23]. NGAL, IL-18, KIM-1, L-FABP, TIMP-2, IGFBP7 and cystatin $C$ are widely investigated biomarkers for AKI in clinical use. Characteristics of these biomarkers are summarized in Table 4.

NGAL, a lipocalin family protein, is a $25 \mathrm{kDa}$ glycoprotein and is covalently bound to neutrophil gelatinase. It is expressed in lung, stomach, colon, and proximal tubular epithelial cells in humans and its expression is markedly increased in response to ischemic kidney or nephrotoxic injury [22-28]. Animal studies and cultured human proximal tubule cell studies have shown that NGAL could be an early marker for ischemia [29-31]. Furthermore, a meta-analysis of data indicated the importance of NGAL in the diagnosis and prognosis of AKI [32]. Therefore, there is strong evidence that urinary and serum NGAL levels are related to kidney injury in the early stages, and that NGAL may be a prognostic marker for AKI. Levels are associated with the need for dialysis and mortality. However, the secretion of NGAL from other tissues during periods of stress is an important disadvantage. It has been demonstrated that patients with several malignancies and patients with sepsis have higher plasma NGAL levels than healthy subjects, and that the level of urinary NGAL is elevated in patients with urinary tract infections [32]. NGAL binding to iron siderophore complexes (holo-NGAL) has bacteriostatic effects and it prevents uptake by bacterial pathogens [32, 33]. Holo-NGAL protects the kidney from ischemia-reperfusion injury, and its synthesis is induced by the kidney-protective enzyme heme oxygenase-1 [33]. It has been reported that the NGAL level increased 3 hours after injury, peaked after about 6 hours, and remained elevated for 5 days [34-36]. Additionally, an elevated plasma NGAL level is al $\neg$ so associated with chronic kidney disease [37].

KIM-1 is a 38.7-kDa type I cell membrane transmembrane tubular glycoprotein protein. Its intracellular domain is a signaling protein for tyrosine phosphorylation. The concentration of KIM is very low in normal kidney tissue and urine [22-26, 38]. After a proximal tubular kidney injury, the extracellular domain of KIM-1 is secreted from damaged cells into the urine in both rats and humans. After epithelial injury, remodeling of the epithelium and the removal of dead cells in the tubular lumen through phagocytosis are achieved by KIM1. The results of animal studies indicated that urinary KIM-1 was a sensitive and specific marker of proximal tubular kidney injury, and that it increased earlier than common biomarkers (e.g., SCr or blood urea nitrogen) [37-45]. Therefore, KIM-1 has been thought to be a marker of kidney injury and that urinary KIM-1 could distinguish ischemic acute tubular necrosis from pre-renal azotemia.

IL-18 is a pro inflammatory cytokine. It is expressed in the cells of the distal tubule and the collecting tubule in the healthy kidney. Human studies show that IL-18 can serve as a marker for proximal tubular damage in acute tubular necrosis [46]. Additionally, it has been shown that IL-18 is a predictive biomarker of AKI after cardiopulmonary bypass, and that the use of both IL-18 and NGAL may be helpful in the management of patients with AKI after cardiopulmonary bypass, since these levels rise before that of $\mathrm{SCr}$ [47]. However, plasma IL-18 levels may be increased as a result of several conditions, such as endotoxemia, inflammatory diseases, and autoimmune diseases $[48,49]$. Due to the fact that IL-18 is a proinflammatory marker, clinical evaluation of a high IL-18 level is problematic for AKI patients with sepsis. Therefore, the sensitivity and specificity of IL-18 for IKA are low [50]. As a result, the use of IL-18 in the management of AKI is limited.

L-FABP is a 14-kDa cytosolic protein synthesized by the liver, intestine, and proximal renal tubule epithelium [22-26, 51, 52]. It binds and carries long-chain fatty acids and protects from toxic cell effects by binding to lipid oxidation products. The human L-FABP gene contains a hypoxia responsive region and hypoxia induces L-FABP gene expression [53]. Studies show that L-FABP has antioxidant properties and that elevation in LFABP expression was protective of the kidney against tubular injury and oxidative damage. [54-60]. Although urinary L-FABP has been accepted as an index marker of renal hypoxia, clinical trials are still limited and inadequate. Prospective studies including multiple causes of kidney disease are needed [5161]. Nonetheless, L-FABP has already been approved for AKI as a diagnostic test in Japan [61].

Cystatin C is a cysteine protease inhibitor of low molecular weight. It is synthesized by all nucleated cells in the body [2226]. Previous studies have indicated that cystatin $C$ may be able to detect early changes in GFR more rapidly than $\mathrm{SCr}$ as the increase in the cystatin $\mathrm{C}$ level is faster and occurs earlier 
than the increase in creatinine level in the patients with AKI $[62,63]$. Cystatin C-based GFR estimation may be appropriate, especially in individuals with a very low $\mathrm{SCr}$ level (such as the elderly, children, renal transplant recipients, or malnourished patients) $[62,63]$. Yet several fac $\neg$ tors, such as thyroid dysfunction, obesity, use of corticosteroids and inflammation agents, older age, male sex, and smoking have been found to be associated with an elevated serum cystatin $C$ level; therefore, its use in AKI is limited [64-68]. Analytical techniques used to measure the cystatin $C$ level have also been developed and immunonephelometric measurements of cystatin $C$ level have become widespread. In a recently published meta-analysis, cystatin $C$ was reported to be the best-performing marker in all clinical conditions associated with AKI in adults. [69].

TIMPs inhibit both matrix metalloproteinases (MMPs) and the proliferation of endothelial cells $[22-26,70,71]$. MMPs have several roles in tissue destruction, fibrosis, weakening of the matrix, and angiogenesis and apoptosis. Therefore, inhibitors of MMPs could have preventive effects in several diseases, such as cancer, neuroinflammatory diseases, atherosclerosis, or aneurysm [72]. TIMP-2 is a 21-kDa protein. TIMP-2 has both antiapoptotic and pro-proliferative effects, and it activates MMP2 , an enzyme that facilitates kidney recovery after ischemiareperfusion injury [73]. Therefore, TIMP-2 has been identified as a strong predictor of development of kidney injury [74]. In contrast to proliferation inhibitory effects, some studies have shown that TIMP-2 promotes cellular proliferation [70]. Therefore, the importance of TIMP-2 levels in the clinical management of AKI is still unclear and additional studies are needed to define the role of TIMP-2 in kidney injury $[74,75]$.

IGFBP7 is a $29-\mathrm{kD}$ protein. It is involved in tumor suppression and regulation of cellular aging through increasing the expression of $\mathrm{p} 21$ and $\mathrm{p} 53$ and inhibiting mitogen-activated protein kinase signaling $[61,71,75,76]$. IGFBP7 is also an IGF-1 receptor antagonist. IGFBP7 secretion by injured tubular epithelial cells has been demonstrated. Therefore, it has been thought that elevated serum IGFBP7 levels may be associated with kidney damage through altering the hemodynamic properties of the kidney. Numerous studies are revealing the importance of IGFBP7 as an IGF-1 antagonist in the treatment of AKI [71, 77]. These studies are very important to demonstrate the usefulness of measuring the IGFBP7 level as an indication for IGF-1 treatment in AKI patients

\section{Conclusion}

Although some biomarkers are correlated with the severity of renal damage, and some biomarker combinations have predictive value for AKI, clinical trials are limited. Multicenter studies are needed to determine the best biomarkers or the best biomarker combination both for the screening and diagnosis of AKI and for the determination of the site of kidney injury. Another important limitation of biomarker research relates to the performance of biomarkers compared with that of $\mathrm{SCr}$ and oliguria, which are not renal-specific and are considered to be inadequate for the diagnosis of AKI. Analytical validation of these biomarker tests is also required. In the literature, there are different AKI definitions and different predictive values are given for markers. Cut-off values of these markers for the prediction of AKI are not yet available. Additionally, biomarker studies are based on en-zyme immunoassays (ELISAs). ELISA methods produce quite different results depending on the reagent used and the duration of the test is very long. The major goal in AKI is to distinguish clinical outcomes by using biomarkers. The use of multiple biomarkers may be required in the management of patients with AKI. According to previous studies, NGAL, KIM-1, IL-18, cystatin C, TIMP-2, and IGFBP7 may be useful in the discrimination of AKI clinical outcomes. However, in order to determine the best combination of biomarkers in the management of AKI and to determine cut-off values of the biomarkers, multicenter studies are needed, as well as resolution of the analytical problems of these biomarkers and development and validation of the methods.

\section{Conflict of interest: None declared.}

\section{References}

1. Chertow GM, Burdick E, Honour M, Bonventre JV, Bates DW. Acute kidney injury, mortality, length of stay, and costs in hospitalized patients. J Am Soc Nephrol 2005;16:3365-70.

2. Parikh A, Shaw A. The economics of renal failure and kidney disease in critically ill patients. Crit Care Clin 2012;28:99-111.

3. Wang HE, Muntner P, Chertow GM, Warnock DG. Acute kidney injury and mortality in hospitalized patients. Am J Nephrol 2012;35:349-55. [CrossRef]

4. Mehboob A, Zimmerman R, Abramson S, Parker MG. Quality measures in acute kidney injury. Curr Opin Nephrol Hypertens 2018;27:130-5. [CrossRef]

5. Yu SM, Bonventre JV. Acute Kidney Injury and Progression of Diabetic Kidney Disease. Adv Chronic Kidney Dis 2018;25:166-80. [CrossRef]

6. Xu J, Jiang W, Shen B, Fang Y, Teng J, Wang $Y$, et al. Acute Kidney Injury in Cardiac Surgery. Contrib Nephrol 2018;193:12736. [CrossRef]

7. Bellomo R, Ronco C, Kellum JA, Mehta RL, Palevsky P; Acute Dialysis Quality Initiative workgroup. Acute renal failure definition, outcome measures, animal models, fluid therapy and information technology needs: the Second International Consensus Conference of the Acute Dialysis Quality Initiative (ADQI) Group. Crit Care 2004;8:R204-12. [CrossRef]

8. Kidney Disease: Improving Global Outcomes (KDIGO) Acute Kidney Injury Work Group KDIGO Clinical Practice Guideline for Acute Kidney Injury. Kidney Int Suppl 2012;2:1-138.

9. Palevsky PM, Liu KD, Brophy PD, Chawla LS, Parikh CR, Thakar CV, et al. KDOQI US commentary on the 2012 KDIGO clinical practice guideline for acute kidney injury. Am J Kidney Dis 2013;61:649-72. [CrossRef]

10. Levey AS, Levin A, Kellum JA. Definition and classification of kidney diseases. Am J Kidney Dis 2013;61:686-8. [CrossRef] 
11. Mehta RL, Kellum JA, Shah SV, Molitoris BA, Ronco C, Warnock DG, et al; Acute Kidney Injury Network. Acute Kidney Injury Network: report of an initiative to improve outcomes in acute kidney injury. Crit Care 2007;11:R31. [CrossRef]

12. Cockcroft DW, Gault MH. Prediction of creatinine clearance from serum creatinine. Nephron 1976;16:31-41. [CrossRef]

13. Doolan PD, Alpen EL, Theil GB. A clinical appraisal of the plasma concentration and endogenous clearance of creatinine. Am J Med 1962;32:65-79. [CrossRef]

14. Kim KE, Onesti G, Ramirez O, Brest AN, Swartz C. Creatinine clearance in renal disease. A reappraisal. Br Med J 1969;4:114. [CrossRef]

15. Levey AS, Bosch JP, Lewis JB, Greene T, Rogers N, Roth D. A more accurate method to estimate glomerular filtration rate from serum creatinine: a new prediction equation. Modification of Diet in Renal Disease Study Group. Ann Intern Med 1999;130:461-70. [CrossRef]

16. Erley CM, Bader BD, Berger ED, Vochazer A, Jorzik JJ, Dietz K, et al. Plasma clearance of iodine contrast media as a measure of glomerular filtration rate in critically ill patients. Crit Care Med 2001;29:1544-50. [CrossRef]

17. Lameire N, Hoste E. Reflections on the definition, classification, and diagnostic evaluation of acute renal failure. Curr Opin Crit Care 2004;10:468-75. [CrossRef]

18. Hoste EA, Damen J, Vanholder RC, Lameire NH, Delanghe JR, Van den Hauwe $\mathrm{K}$, et al. Assessment of renal function in recently admitted critically ill patients with normal serum creatinine. Nephrol Dial Transplant 2005;20:747-53. [CrossRef]

19. Van Biesen W, Vanholder R, Veys N, Verbeke F, Delanghe J, De Bacquer $D$, et al. The importance of standardization of creatinine in the implementation of guidelines and recommendations for CKD: implications for CKD management programmes. Nephrol Dial Transplant 2006;21:77-83. [CrossRef]

20. Thomas ME, Blaine C, Dawnay A, Devonald MA, Ftouh S, Laing $C$, et al. The definition of acute kidney injury and its use in practice. Kidney Int 2015;87:62-73. [CrossRef]

21. Ho J, Tangri N, Komenda P, Kaushal A, Sood M, Brar R, et al. Urinary, Plasma, and Serum Biomarkers' Utility for Predicting Acute Kidney Injury Associated With Cardiac Surgery in Adults: A Meta-analysis. Am J Kidney Dis 2015;66:993-1005.

22. Ostermann M, Philips BJ, Forni LG. Clinical review: Biomarkers of acute kidney injury: where are we now? Crit Care 2012;16:233. [CrossRef]

23. Murray PT, Mehta RL, Shaw A, Ronco C, Endre Z, Kellum JA, et al. Potential use of biomarkers in acute kidney injury: report and summary of recommendations from the 10th Acute Dialysis Quality Initiative consensus conference. Kidney Int 2014;85:513-21. [CrossRef]

24. Belcher JM, Edelstein CL, Parikh CR. Clinical applications of biomarkers for acute kidney injury. Am J Kidney Dis 2011;57:930-40. [CrossRef]

25. Sirota JC, Klawitter J, Edelstein CL. Biomarkers of acute kidney injury. J Toxicol 2011;2011:328120. [CrossRef]

26. Klein SJ, Brandtner AK, Lehner GF, Ulmer H, Bagshaw SM, Wiedermann $\mathrm{CJ}$, et al. Biomarkers for prediction of renal re- placement therapy in acute kidney injury: a systematic review and meta-analysis. Intensive Care Med 2018;44:323-36.

27. Teo $\mathrm{SH}$, Endre $\mathrm{ZH}$. Biomarkers in acute kidney injury (AKI). Best Pract Res Clin Anaesthesiol 2017;31:331-44. [CrossRef]

28. Flower DR, North AC, Sansom CE. The lipocalin protein family: structural and sequence overview. Biochim Biophys Acta 2000;1482:9-24. [CrossRef]

29. Mishra J, Ma Q, Prada A, Mitsnefes M, Zahedi K, Yang J, et al. Identification of neutrophil gelatinase-associated lipocalin as a novel early urinary biomarker for ischemic renal injury. J Am Soc Nephrol 2003;14:2534-43. [CrossRef]

30. Mishra J, Dent C, Tarabishi R, Mitsnefes MM, Ma Q, Kelly C, et al. Neutrophil gelatinase-associated lipocalin (NGAL) as a biomarker for acute renal injury after cardiac surgery. Lancet 2005;365:1231-8. [CrossRef]

31. Mishra J, Mori K, Ma Q, Kelly C, Barasch J, Devarajan P. Neutrophil gelatinase-associated lipocalin: a novel early urinary biomarker for cisplatin nephrotoxicity. Am J Nephrol 2004;24:307-15. [CrossRef]

32. Zhang A, Cai Y, Wang PF, Qu JN, Luo ZC, Chen XD, et al. Diagnosis and prognosis of neutrophil gelatinase-associated lipocalin for acute kidney injury with sepsis: a systematic review and meta-analysis. Crit Care 2016;20:41. [CrossRef]

33. Flo TH, Smith KD, Sato S, Rodriguez DJ, Holmes MA, Strong RK, et al. Lipocalin 2 mediates an innate immune response to bacterial infection by sequestrating iron. Nature 2004;432:917-21. [CrossRef]

34. Bennett M, Dent CL, Ma Q, Dastrala S, Grenier F, Workman $\mathrm{R}$, et al. Urine NGAL predicts severity of acute kidney injury after cardiac surgery: a prospective study. Clin J Am Soc Nephrol 2008;3:665-73. [CrossRef]

35. Mcllroy DR, Wagener G, Lee HT. Neutrophil gelatinase-associated lipocalin and acute kidney injury after cardiac surgery: the effect of baseline renal function on diagnostic performance. Clin J Am Soc Nephrol 2010;5:211-9. [CrossRef]

36. Singer E, Elger A, Elitok S, Kettritz R, Nickolas TL, Barasch J, et al. Urinary neutrophil gelatinase-associated lipocalin distinguishes pre-renal from intrinsic renal failure and predicts outcomes. Kidney Int 2011;80:405-14. [CrossRef]

37. Moriya H, Mochida Y, Ishioka K, Oka M, Maesato K, Hidaka $S$, et al. Plasma neutrophil gelatinase-associated lipocalin (NGAL) is an indicator of interstitial damage and a predictor of kidney function worsening of chronic kidney disease in the early stage: a pilot study. Clin Exp Nephrol 2017;21:10539. [CrossRef]

38. Ichimura T, Bonventre JV, Bailly V, Wei H, Hession CA, Cate RL, et al. Kidney injury molecule-1 (KIM-1), a putative epithelial cell adhesion molecule containing a novel immunoglobulin domain, is up-regulated in renal cells after injury. J Biol Chem 1998;273:4135-42. [CrossRef]

39. Ichimura T, Asseldonk EJ, Humphreys BD, Gunaratnam L, Duffield JS, Bonventre JV. Kidney injury molecule-1 is a phosphatidylserine receptor that confers a phagocytic phenotype on epithelial cells. J Clin Invest 2008;118:1657-68.

40. Vaidya VS, Ramirez V, Ichimura T, Bobadilla NA, Bonventre 
JV. Urinary kidney injury molecule-1: a sensitive quantitative biomarker for early detection of kidney tubular injury. Am J Physiol Renal Physiol 2006;290:F517-29. [CrossRef]

41. Liangos O, Perianayagam MC, Vaidya VS, Han WK, Wald $\mathrm{R}$, Tighiouart $\mathrm{H}$, et al. Urinary $\mathrm{N}$-acetyl-beta-(D)-glucosaminidase activity and kidney injury molecule-1 level are associated with adverse outcomes in acute renal failure. J Am Soc Nephrol 2007;18:904-12. [CrossRef]

42. Bonventre JV. Kidney injury molecule-1 (KIM-1): a urinary biomarker and much more. Nephrol Dial Transplant 2009;24(:3265-8.

43. Chaturvedi S, Farmer T, Kapke GF. Assay validation for KIM1: human urinary renal dysfunction biomarker. Int J Biol Sci 2009;5:128-34. [CrossRef]

44. de Geus HR, Betjes MG, Bakker J. Biomarkers for the prediction of acute kidney injury: a narrative review on current status and future challenges. Clin Kidney J 2012;5:102-8.

45. Pozzoli S, Simonini M, Manunta P. Predicting acute kidney injury: current status and future challenges. J Nephrol 2018;31:209-23. [CrossRef]

46. Melnikov VY, Faubel S, Siegmund B, Lucia MS, Ljubanovic D, Edelstein CL. Neutrophil-independent mechanisms of caspase-1- and IL-18-mediated ischemic acute tubular necrosis in mice. J Clin Invest 2002;110:1083-91. [CrossRef]

47. Parikh CR, Mishra J, Thiessen-Philbrook H, Dursun B, Ma Q, Kelly $C$, et al. Urinary IL-18 is an early predictive biomarker of acute kidney injury after cardiac surgery. Kidney Int 2006;70:199-203. [CrossRef]

48. Haase M, Bellomo R, Story D, Davenport P, Haase-Fielitz A. Urinary interleukin-18 does not predict acute kidney injury after adult cardiac surgery: a prospective observational cohort study. Crit Care 2008;12:R96. [CrossRef]

49. Kaplanski G. Interleukin-18: Biological properties and role in disease pathogenesis. Immunol Rev 2018;281:138-53.

50. Liu Y, Guo W, Zhang J, Xu C, Yu S, Mao Z, et al. Urinary interleukin 18 for detection of acute kidney injury: a meta-analysis. Am J Kidney Dis 2013;62:1058-67. [CrossRef]

51. Sweetser DA, Heuckeroth RO, Gordon Jl. The metabolic significance of mammalian fatty-acid-binding proteins: abundant proteins in search of a function. Annu Rev Nutr 1987;7:337-59. [CrossRef]

52. Smathers RL, Petersen DR. The human fatty acid-binding protein family: evolutionary divergences and functions. Hum Genomics 2011;5:170-91. [CrossRef]

53. Supavekin S, Zhang W, Kucherlapati R, Kaskel FJ, Moore LC, Devarajan P. Differential gene expression following early renal ischemia/reperfusion. Kidney Int 2003;63:1714-24.

54. Nakamura T, Sugaya T, Node K, Ueda Y, Koide H. Urinary excretion of liver-type fatty acid-binding protein in contrast medium-induced nephropathy. Am J Kidney Dis 2006;47:439-44.

55. Negishi K, Noiri E, Sugaya T, Li S, Megyesi J, Nagothu K, et al. A role of liver fatty acid-binding protein in cisplatin-induced acute renal failure. Kidney Int 2007;72:348-58. [CrossRef]

56. Portilla D, Dent C, Sugaya T, Nagothu KK, Kundi I, Moore P, et al. Liver fatty acid-binding protein as a biomarker of acute kidney injury after cardiac surgery. Kidney Int 2008;73:46572. [CrossRef]

57. Yamamoto T, Noiri E, Ono Y, Doi K, Negishi K, Kamijo A, et al. Renal L-type fatty acid-binding protein in acute ischemic injury. J Am Soc Nephrol 2007;18:2894-902. [CrossRef]

58. Ferguson MA, Vaidya VS, Waikar SS, Collings FB, Sunderland $\mathrm{KE}$, Gioules $\mathrm{CJ}$, et al. Urinary liver-type fatty acid-binding protein predicts adverse outcomes in acute kidney injury. Kidney Int 2010;77:708-14. [CrossRef]

59. Doi K, Noiri E, Sugaya T. Urinary L-type fatty acid-binding protein as a new renal biomarker in critical care. Curr Opin Crit Care 2010;16:545-9. [CrossRef]

60. Parikh CR, Thiessen-Philbrook H, Garg AX, Kadiyala D, Shlipak MG, Koyner JL, et al. Performance of kidney injury molecule-1 and liver fatty acid-binding protein and combined biomarkers of AKI after cardiac surgery. Clin J Am Soc Nephrol 2013;8:1079-88. [CrossRef]

61. Alge JL, Arthur JM. Biomarkers of AKI: a review of mechanistic relevance and potential therapeutic implications. Clin J Am Soc Nephrol 2015;10:147-55. [CrossRef]

62. Dharnidharka VR, Kwon C, Stevens G. Serum cystatin C is superior to serum creatinine as a marker of kidney function: a meta-analysis. Am J Kidney Dis 2002;40:221-6. [CrossRef]

63. Herget-Rosenthal S, Marggraf G, Hüsing J, Göring F, Pietruck F, Janssen $\mathrm{O}$, et al. Early detection of acute renal failure by serum cystatin C. Kidney Int 2004;66:1115-22. [CrossRef]

64. Knight EL, Verhave JC, Spiegelman D, Hillege HL, de Zeeuw $D$, Curhan GC, et al. Factors influencing serum cystatin $C$ levels other than renal function and the impact on renal function measurement. Kidney Int 2004;65:1416-21. [CrossRef]

65. Herget-Rosenthal S, Pietruck F, Volbracht L, Philipp T, Kribben A. Serum cystatin C--a superior marker of rapidly reduced glomerular filtration after uninephrectomy in kidney donors compared to creatinine. Clin Nephrol 2005;64:41-6. [CrossRef]

66. Pöge U, Gerhardt T, Stoffel-Wagner B, Palmedo H, Klehr HU, Sauerbruch T, et al. Cystatin C-based calculation of glomerular filtration rate in kidney transplant recipients. Kidney Int 2006;70:204-10. [CrossRef]

67. Koyner JL, Parikh CR. Clinical utility of biomarkers of AKI in cardiac surgery and critical illness. Clin J Am Soc Nephrol 2013;8:1034-42. [CrossRef]

68. Eriksen BO, Mathisen UD, Melsom T, Ingebretsen OC, Jenssen TG, Njølstad I, et al. Cystatin C is not a better estimator of GFR than plasma creatinine in the general population. Kidney Int 2010;78:1305-11. [CrossRef]

69. Yong Z, Pei X, Zhu B, Yuan H, Zhao W. Predictive value of serum cystatin $C$ for acute kidney injury in adults: a metaanalysis of prospective cohort trials. Sci Rep 2017;7:41012.

70. Stetler-Stevenson WG. Tissue inhibitors of metalloproteinases in cell signaling: metalloproteinase-independent biological activities. Sci Signal 2008;1:re6. [CrossRef]

71. Kashani K, Al-Khafaji A, Ardiles T, Artigas A, Bagshaw SM, Bell $M$, et al. Discovery and validation of cell cycle arrest biomarkers in human acute kidney injury. Crit Care 2013;17:R25.

72. Amălinei C, Căruntu ID, Giuşcă SE, Bălan RA. Matrix metal- 
loproteinases involvement in pathologic conditions. Rom J Morphol Embryol 2010;51:215-28.

73. Catania JM, Chen G, Parrish AR. Role of matrix metalloproteinases in renal pathophysiologies. Am J Physiol Renal Physiol 2007;292:F905-11. [CrossRef]

74. Parrish AR. Matrix Metalloproteinases in Kidney Disease: Role in Pathogenesis and Potential as a Therapeutic Target. Prog Mol Biol Transl Sci 2017;148:31-65. [CrossRef]

75. Aregger F, Uehlinger DE, Witowski J, Brunisholz RA, Hunziker P, Frey FJ, et al. Identification of IGFBP-7 by urinary pro- teomics as a novel prognostic marker in early acute kidney injury. Kidney Int 2014;85:909-19. [CrossRef]

76. Ding H, Kopple JD, Cohen A, Hirschberg R. Recombinant human insulin-like growth factor-I accelerates recovery and reduces catabolism in rats with ischemic acute renal failure. J Clin Invest 1993;91:2281-7. [CrossRef]

77. Hirschberg R, Kopple J, Lipsett P, Benjamin E, Minei J, Albertson $T$, et al. Multicenter clinical trial of recombinant human insulin-like growth factor I in patients with acute renal failure. Kidney Int 1999;55:2423-32. [CrossRef] 